\title{
Do tablado às livrarias \\ edição e transmissão de textos teatrais no Rio de Janeiro da segunda metade do século $\mathrm{XIX}^{*}$
}

\section{From the stage to the bookstores \\ theatrical texts' edition and diffusion in Rio Janeiro at the second half of the XIX ${ }^{\text {th }}$ century ${ }^{* *}$}

\author{
SILVIA CRISTINA MARTINS DE SOUZA \\ Professora Adjunta do Departamento de História da Universidade Estadual de Londrina \\ Doutora pela Universidade Estadual de Campinas \\ Rodovia Celso Garcia Cid, PR 445, Km 380. Campus Universitário \\ C 6001 Cep 86055-900. Londrina. Paraná \\ smartins@uel.br
}

RESUMO Neste artigo serão exploradas as relações entre texto e oralidade e entre edição e transmissão de textos teatrais com o objetivo de mostrar que o estudo da materialidade dos textos e suas modalidades de transmissão são essenciais para a compreensão das múltiplas formas de recepção e de apropriação, aspectos caros à chamada história da leitura. O corpus documental analisado é composto por peças teatrais comercializadas no mercado livreiro do Rio de Janeiro na segunda metade do século XIX que constam do acervo da Biblioteca Nacional e do Real Gabinete Português de Leitura.

Palavras-chave história da leitura, recepção, apropriação

ABSTRACT In this article we intend to explore the relations between written text and orality, as well as relations between edition and diffusion of theatrical

Artigo recebido em: 03/12/2008. Aprovado em: 18/06/2009

** Agradeço ao CNPq o auxílio à pesquisa, através de bolsa que viabilizou o estágio pós-doutoral junto à Universidade Federal Fluminense, do qual este artigo apresenta alguns resultados parciais. 
texts. We intend to demonstrate that the study of the materiality of these texts and its sorts of diffusion are essential for the understanding of the multiple forms of reception and appropriation, very important aspects of the history of reading. The documental corpus is composed by theatrical pieces marketed in Rio de Janeiro's bookseller trade at the second half of XIX century. These pieces are from the collections of Biblioteca Nacional and Real Gabinete Português de Leitura.

Key words history of reading, reception, appropriation

Na edição da sua comédia Disto há muito!, o dramaturgo Thomás Aquino Borges adicionou um prólogo ao qual intitulou Emendas. Inicialmente invocando a figura de dois atores, aos quais dedicava a obra, este prólogo muda, contudo, de natureza, censurando os compositores gráficos, com o autor finalizando com as seguintes palavras:

Não tendo sido revistas pelo autor algumas provas da Impressão, pede aos amáveis leitores de sua obra o especialíssimo obséquio de reverem algumas faltas que nela encontrarem, devidas ao descuido dos compositores, - como sejam: - em algumas frases, a separação ortográfica do nome dos personagens para o acionado, e palavras que por serem viciadas e outras sem propriedade deviam estar sublinhadas. ${ }^{1}$

A expressão "devidas ao descuido dos compositores", utilizada por Thomás Aquino Borges, remete a algo que foi muito comum ao mundo editorial do século XIX no Rio de Janeiro, isto é, a circulação de exemplares contendo erros tipográficos, um desdobramento da intensificação do processo de publicação de textos teatrais, que tomou corpo a partir de fins dos anos 1850.

Os prólogos, introduções, emendas e advertências de muitos dos textos publicados neste período, assim como vários pareceres de censuras de peças que foram remetidas ao Conservatório Dramático, são pródigos em mencionar tal fato. Neles são apontados como causa da circulação de tais publicações, motivos que vão desde uma suposta ignorância ou negligência dos tipógrafos até os interesses de um mercado livreiro, que utilizava métodos de edição lestos, mas pouco rigorosos, visando atender às demandas de um público ávido pelas novidades que acabavam de conhecer nos tablados e poderiam ser rapidamente adquiridas nas prateleiras das livrarias, lojas de alfarrabistas ou através de vendedores ambulantes. ${ }^{2}$

1 RIBEIRO, Thomás Aquino. Disto há muito!. Rio de Janeiro: Tipografia Popular de Azeredo Leite, 1862. (Biblioteca Nacional, Divisão de Obras Raras).

2 No parecer emitido pelo censor do Conservatório Dramático Brasileiro à cena cômica O tio Mateus, visita de amizade, de Batista Machado, os tipógrafos e copistas também foram alvos de ácidas críticas. Nele, o censor diria 
Um outro fato chama atenção neste prólogo, uma vez que nele o dramaturgo solicitava aos leitores de sua comédia "o obséquio de reverem algumas faltas que nela encontrarem", convidando-os a corrigir seus exemplares de acordo com uma errata que adicionava à edição. Desta maneira, Thomaz Aquino Borges acenava com uma oportunidade ímpar - ainda que não fosse exatamente esta a sua intenção - de os leitores participarem do processo de construção de seu trabalho, já que o exercício de correção dos erros podia ser enriquecido ou transformado a partir das expectativas e juízos dos próprios leitores, escapando ao controle e aos objetivos prefigurados pelo autor.

O convite feito por este dramaturgo aos seus leitores é sugestivo na medida em que ele aponta para uma questão crucial para os estudos da história da leitura alertando para a questão de que, aparentemente passiva e submissa, a leitura é, em si, inventiva e criativa, seja ela solitária ou comunitária. Tal questão, por sua vez, nos remete à noção de que os sentidos não são inerentes aos textos e dependem de diferentes momentos de transmissão, isto é, da redação da obra, das decisões editoriais, da composição tipográfica, da revisão das provas, da impressão, da representação teatral e das leituras.

Em ensaio intitulado As revoluções da leitura no Ocidente, Roger Chartier explora esta questão, e oferece algumas possibilidades metodológicas para abordagem do assunto. Segundo ele, o historiador deve estar atento para a íntima ligação existente entre as formas de oralidade e a edição de livros, pois não se deve deixar de ter no horizonte que grande parte dos textos teatrais impressos no passado não prefiguravam de modo algum o leitor solitário como seu destinatário. ${ }^{3}$

Compostos para serem lidos em voz alta, vislumbrando um tipo de leitura denominada intensiva, tais textos obedeciam a leis e regras próprias à transmissão oral e comunitária, decorrendo disto a importância de uma história da leitura que enfatize a historicidade das diferenças morfológicas que afetam o significado do que é lido. ${ }^{4}$

No Rio de Janeiro da segunda metade do século XIX, a publicação de textos teatrais em edições in oitavo e in décimo-segundo, vendidas a preços

que "alguns versos, que não designo por não achar necessário estão, uns falhos ao metro, outros às da eufonia (...), mas convenço-me que estes defeitos provém do copista porque tipógrafos, com raras exceções e copistas quase sem nenhuma fazem uma raça de algozes sempre dispostos à estrangulação das obras dos autores" (Biblioteca Nacional, Divisão de Manuscritos, Coleção Conservatório Dramático Brasileiro). Uma interessante análise sobre as queixas dos homens de letras brasileiras quanto à qualidade dos trabalhos tipográficos e sobre as representações construídas è época sobre os tipógrafos foi elaborada por SCHAPOCHNICK, Nelson. Malditos tipógrafos. In: / Seminário Brasileiro sobre Livro e História Editorial. Rio de Janeiro: FCRB/UFF, 2004.

3 CHARTIER, Roger. As revoluções da leitura no Ocidente. In: ABREU, Márcia. (org.) Leitura, história e história da leitura. Campinas: Mercado das Letras, 2002, p.30

4 CHARTIER, Roger. As revoluções da leitura no Ocidente, p.21. 
bastante accessíveis, tornou-se uma verdadeira febre. ${ }^{5}$ Nos catálogos de diferentes livrarias existentes na cidade, em anexos inseridos às edições das peças ou nas sessões de anúncios de jornais é possível encontrar-se listas contendo dezenas de títulos de comédias, cenas cômicas, monólogos, intermédios, entreatos, tragédias e dramas, todos eles accessíveis aos mais diferentes gostos e bolsos fluminenses do período. ${ }^{6}$

Tal foi a extensão deste comércio que poderíamos sugerir que os textos teatrais contribuíram de forma efetiva para movimentar um vasto universo permeado por diferentes gêneros literários, que alcançaram grande repercussão depois de conseguirem uma forma material capaz de reduzir seus preços e conquistar a atenção de um número cada vez mais diversificado de consumidores.

Em se tratando de uma sociedade com alto índice de analfabetismo, na qual a leitura em voz alta e comunitária era uma das mais importantes formas de circulação e apropriação de textos, este é um dado importante, na medida em que ele nos permite elaborar algumas reflexões a respeito dos modos de circulação e apropriação de obras e gêneros literários cujos usos e funções não eram sugeridos nem pelo texto impresso, nem pelos hábitos da leitura silenciosa e solitária. ${ }^{7}$ Afinal, quem ouve, assim como quem lê, está, simultaneamente, buscando significados, recorrendo a significantes, buscando sons e sentidos, ritmos e formas. Neste movimento, formam-se redes que envolvem textos, leitores e ouvintes, e os modos de sentir, pensar e agir migram e impregnam uns e outros.

A orientação que presidiu este texto foi explorar o terreno fecundo das relações entre texto e oralidade e entre edição e os diferentes tipos de transmissão prefigurados pelos autores para suas obras. Para tanto nos debruçaremos sobre um corpus documental composto por algumas peças teatrais que foram encenadas em diferentes teatros do Rio e comercializadas no mercado livreiro da Corte na segunda metade do século XIX, procurando vislumbrar nos seus textos, advertências, prólogos, introduções e na sua estrutura formal, como um todo, indicadores morfológicos que possam servir para localizarmos indícios de como elas deveriam ser lidas

5 Os termos utilizados no século XIX para indicar o tamanho aproximado de um livro derivavam do número de folhas dobradas. O in folio era o maior tamanho e resultava de uma única dobra da folha a ser impressa produzindo quatro páginas; o in quarto resultava de duas dobras ou oito páginas; o in oitavo era resultante de três dobraduras originando dezesseis páginas e, por fim, o in décimo-segundo, que resultava de quatro dobraduras.

6 Ver, a este respeito, os vários exemplares de edições de peças teatrais publicadas na segunda metade do século XIX, que fazem parte do acervo do Real Gabinete Português de Leitura.

7 É ainda Chartier quem nos chama atenção para o fato de que os hábitos de leitura dos leitores mais populares e numerosos foram direcionados por longo tempo pela leitura em voz alta, compartilhada por um público ouvinte. No século XIX, a industrialização da produção de impressos e a emergência de novas categorias de leitores (mulheres, crianças, trabalhadores) trouxeram novos materiais e novos modos de leitura, sendo esta grande diversidade de práticas de leitura e de comércio de impressos que rompe com qualquer possibilidade de pensar numa cultura compartilhada que seja fruto da alfabetização. CHARTIER, Roger. As revoluções da leitura no Ocidente, p.21-25. 
em voz alta e compartilhadas por um público ouvinte. ${ }^{8}$ Tal objetivo tem em vista mostrar, a partir da análise de situações concretas, que o estudo da materialidade dos textos e suas modalidades de transmissão são essenciais para a compreensão das múltiplas formas de recepção e de apropriação, aspectos tão caros à chamada história da leitura.

Espera-se adicionalmente que, ao final do texto, o leitor possa visualizar uma realidade diferente daquela divulgada pelos compêndios tradicionais de história do teatro sobre este período, e que possa entender melhor porque uma variedade significativa de brochuras e impressões baratas, esquecidas ao longo dos anos, foi capaz de atuar de modo decisivo na consolidação do mercado livreiro fluminense do oitocentos.

O Rio de Janeiro da década de 1860 era uma cidade que passava por um processo de aceleração de crescimento e por modificações estruturais significativas, mudanças estas iniciadas na década anterior, quando o fechamento do tráfico de escravos liberou capitais que foram investidos em diferentes setores. Dentre estes setores, dois nos interessam particularmente: o de divertimentos públicos, mais especificamente o teatro, e o mercado livreiro. Foi ao longo da década de 1860 que o número de teatros em funcionamento na cidade mais que duplicou.

Decisiva para este crescimento foi a propagação de diferentes gêneros do teatro musicado nos quais investiram não apenas empresários da terra, como também empresários estrangeiros, que passaram a visitar a cidade regularmente com suas companhias teatrais ou nela se fixaram com intenção de melhor explorar seus negócios.

Também importante para este processo, a que vimos nos referindo, foi a inauguração do Alcazar Lírico, pelo francês Mr. Arnaud, em inícios de 1859. O Alcazar foi uma casa de espetáculos que se tornou responsável pela introdução das cançonetas, paródias, operetas - sem que contar do cancã - nos tablados da Corte. Como observou Fernando Mencarelli, foi o Alcazar, com seu sucesso, que consolidou "uma visão do espetáculo como divertimento urbano, trazendo a novidade de um teatro musicado que correspondia às demandas por entretenimento geradas pela população cada vez mais heterogênea que se instalava nas cidades em processo de modernização", fenômeno do qual o Rio de Janeiro não esteve ausente. ${ }^{9}$ O sucesso do Alcazar levou outras companhias teatrais a apostarem num repertório similar ao seu. Neste processo, descortinou-se, para diferentes

8 Os textos teatrais citados neste artigo foram consultados na Biblioteca Nacional e no Real Gabinete Português de Leitura (Rio de Janeiro).

9 MENCARELLI, Fernando A. A voz e a partitura: teatro musical, indústria e diversidade cultural no Rio de Janeiro (1868-1908). Campinas: Unicamp, p.283. (História, Tese de Doutorado). 
sujeitos envolvidos com o fazer teatral, o potencial de num novo negócio que iria operar uma mudança de escala significativa na produção teatral da cidade nas décadas seguintes.

Como um desdobramento deste sucesso que os tablados começaram a experimentar, um outro setor foi alavancado: o mercado livreiro voltado para a publicação e comercialização de textos teatrais. Diferentemente do que ocorreu entre os anos de 1819 e 1833 quando, de acordo com Laurence Hallewell, a existência de um setor dedicado à produção e comércio livreiro especializado em língua portuguesa na França foi responsável pela vinda de obras de diferentes naturezas deste país para o Brasil, fazendo com que filiais de livrarias francesas se instalassem no Rio, ${ }^{10}$ os últimos anos da década de 1850 e as décadas seguintes vivenciaram uma outra realidade.

Uma rápida passagem de olhos pelos anúncios de livrarias publicados em diferentes jornais fluminenses ou por alguns de seus catálogos, que foram preservados nos arquivos públicos do Rio de Janeiro, ilumina a presença representativa dos exemplares de peças escritas em português e editadas em Portugal, que foram comercializadas à exaustão na capital do império, a ponto de alimentarem uma ampla discussão sobre a questão da propriedade literária nos dois países, uma vez que no Brasil inexistiam leis que garantissem os direitos autorais na ocasião. ${ }^{11}$

Aproveitando-se da proximidade lingüística e cultural, muitos livreiros portugueses exploraram seus negócios no Rio contando, para o bom andamento dos seus trabalhos, com a cooperação de conterrâneos estabelecidos nesta cidade, com os quais firmaram contratos de parceria, compra, venda ou distribuição. Exemplar deste fenômeno é o caso da Livraria Cruz Coutinho, que surgiu no Rio como propriedade do português Antônio Augusto da Cruz Coutinho, irmão de um conhecido livreiro e editor do Porto de nome Antônio Rodrigues da Cruz Coutinho. As relações de parentesco entre os dois facilitaram a vinda de obras de Portugal para o Brasil traduzidas do francês, mas, sobretudo, originais portugueses. ${ }^{12} \mathrm{Ou}$ ainda o caso do fluminense Francisco de Paula Brito, primeiro editor a publicar trabalhos de autores brasileiros, mas que também foi correspondente, no

10 HALLEWELL, Laurence. O livro no Brasil: sua história. São Paulo: T.A Queiroz Editor/Editora da USP, 2005, p.130.

11 Até 1898 não havia no Brasil nenhuma lei regulamentando os direitos autorais. O artigo 261 do Código Criminal do Império, de dezembro de 1830, rezava que era crime "imprimir, gravar, litografar ou introduzir quaisquer escritos ou estampas que tivessem sido produzidos, compostos ou traduzidos por cidadãos brasileiros enquanto estes viverem e dez anos depois de sua morte se deixarem herdeiros". Este artigo, todavia, parece ter permanecido letra morta até a república, quando surgiu a primeira lei versando sobre direitos autorais. Sobre as querelas em torno da propriedade literária envolvendo autores brasileiros e portugueses ver: FERREIRA, Tânia Maria Bessone da Cruz. Direito de propriedade ou propriedade literária: os debates sobre a autoria no Brasil Imperial (1862-1884). In: I Seminário Brasileiro sobre Livro e História Editorial.

12 Ver: BERGER, Paulo. A tipografia no Rio de Janeiro: impressores bibliográficos (1808-1900). Rio de Janeiro: Imprensa Nacional, 1984, p.119. 
Rio, da empresa portuguesa denominada Teatro Moderno, de propriedade do dramaturgo Francisco Palha e de seu sócio M. Cobellos, um indivíduo também envolvido com o mundo teatral.

Para a divulgação das edições que recebia de Portugal, Paula Brito utilizava-se das páginas do seu jornal Marmota Fluminense, nas quais estampava anúncios de muitas destas obras ou excertos e/ou textos completos das mesmas, neste último caso sob forma de folhetins, chamando a atenção dos prováveis consumidores para elas. ${ }^{13}$

Mas o Rio de Janeiro não se limitou a comprar e vender exemplares editados em Lisboa e no Porto; as atividades editoriais e livreiras da cidade também se dinamizaram. O número de suas tipografias e livrarias cresceu progressivamente a partir de inícios dos anos 1860, o que indica o potencial que este comércio passou a oferecer aos comerciantes de livros.

Para que se tenha idéia da expansão deste setor, poderíamos citar alguns números. Nos anos de 1858, as livrarias do Rio não passavam de treze; no ano 1868 elas já seriam vinte e três e, no ano 1870, o número de estabelecimentos que vendiam livros girou em torno de trinta. As tipografias e editoras, neste mesmo período, cresceram de cinco para onze entre 1858 e 1868, atingindo a marca de vinte e duas na década de $1870 .{ }^{14}$ Neste movimento, passaram a atuar ao lado dos nomes famosos de Garnier, Laemmert e Lombaerts, empresas hoje desconhecidas tais como as tipografias de Cruz Coutinho, a de Azeredo Leite, a de J.J. da Rocha, a de Domingos José de Brandão e a da Rua do Cano, apenas para citarmos alguns nomes. ${ }^{15}$ A tipografia Cruz Coutinho, por exemplo, manteve até os anos 1880 uma coleção intitulada Teatro Moderno Luso-Brasileiro, editada no Brasil, da qual constavam cento e onze títulos de textos teatrais em diferentes gêneros sendo que mais de $60 \%$ deles era de autores brasileiros.

Vê-se, assim, que teatro e mercado livreiro alimentaram-se reciprocamente criando oportunidades para que diferentes leitores adquirissem os textos das peças cujas histórias já conheciam das representações teatrais, consolidando uma apropriação baseada menos na descoberta de novidades e mais na identificação de temas e formas conhecidos.

Publicar os textos das peças quase que ou, em certos casos, simultaneamente às estréias das mesmas, tornou-se prática disseminada. Geralmente impressas em brochuras baratas, vendidas em livrarias, por vendedores ambulantes ou pelos próprios autores por preços que variam

13 Ver, por exemplo, o exemplar da Marmota Fluminense de 28 de julho de 1858

14 Ver: Almanack administrativo, mercantil e industrial da corte e da província. Rio de Janeiro, E\&H. Laemmert) para os anos citados. Devemos deixar claro que este é um dado aproximado, pois nem todos os comerciantes de livros enviavam as informações solicitadas pela Livraria Laemmert para serem anexadas ao almanaque.

15 Maiores informações sobre estas e outras tipografias podem ser encontradas em BERGER, Paulo. A tipografia no Rio de Janeiro: impressores bibliográficos (1808-1900). 
de quatrocentos a mil réis, estes "livrinhos" (tal como pejorativamente eram denominados à época) acabaram por atingir um amplo público. ${ }^{16}$

Diante deste fato, pode-se mesmo sugerir que a representação das peças funcionava como uma espécie de propaganda para a venda dos exemplares impressos que, dependendo da popularidade do autor, ficavam garantidas a priori. Muitos dos prólogos e advertências de vários destes textos nos dão conta deste fenômeno, como é o caso da segunda edição da paródia Orfeu na roça, do ator e dramaturgo fluminense Francisco Correa Vasques.

Intitulada Antes da leitura, a advertência anexada pelo autor ao texto esclarecia aos leitores que o motivo que o levara a imprimi-lo fora criar condições para que o público "pudesse apreciar mais de perto o espírito da paródia, se é que o tem". ${ }^{17} \mathrm{O}$ tom de modéstia em que se reveste tal fala, em se tratando de um dramaturgo que, por ocasião da estréia desta paródia, já escrevera, encenara e publicara mais da metade dos textos que compõem sua extensa obra dramática, pode ser entendido como uma estratégia por ele adotada para chamar a atenção de seus potenciais leitores. ${ }^{18}$ Uma estratégia, vale acrescentar, bastante atrativa, pois transferia para os leitores uma tarefa reservada aos críticos teatrais, atribuindo-Ihes a prerrogativa de julgar o valor artístico da obra que lhe chegava às mãos, permitindo-Ihes contribuir de maneira mais efetiva para a trajetória que a peça percorreria nos tablados e nas livrarias. E a julgar pelo fato de que Orfeu na Roça foi encenada por mais de cem representações consecutivas e o texto impresso teve uma segunda edição, pode-se dizer que a intenção de Vasques foi contemplada.

Para além deste fato, este prólogo também nos permite perceber como seu autor indicava a diferença entre a peça como encenação e como composição, sugerindo que os leitores do texto poderiam ter a oportunidade adicional de acolherem a obra de maneira mais próxima da qual ela fora por ele concebida. Desta maneira, Vasques procurava cativar espectadores e leitores, prefigurando um duplo público para sua obra valorizando, simultaneamente, o ato da impressão da sua paródia e a importância da leitura da mesma.

Se acrescentarmos aos elementos que vimos arrolando o da prática de leitura em voz alta, bastante corrente entre os mais diversos segmen-

16 Apenas para que se tenha uma idéia do preço de tais edições poderíamos mencionar que um carroceiro ganhava por dia 1.120 réis; um mestre carpinteiro, 3 mil réis e um carpinteiro 500 réis.

17 VASQUES, Francisco Correa. Orfeu na roça. $2^{\mathrm{a}}$ ed. Rio de Janeiro: Livraria Cruz Coutinho, 1873. A primeira edição da peça veio à luz no dia 30 de outubro de 1868, o mesmo da estréia da paródia no teatro Fênix Dramática. Francisco Correa Vasques era fluminense, mulato, de parca educação formal, e notabilizou-se como ator e dramaturgo, embora na história do teatro brasileiro sua faceta de dramaturgo seja muito pouco valorizada.

18 Ao longo dos trinta e quatro anos de sua carreira artística, Vasques escreveu mais de sessenta peças teatrais, a maior parte delas no decorrer da década de 1860. De tal forma os seus textos tiveram boa aceitação entre os leitores que, no dia 31 de dezembro de 1864, o Jornal do Comércio publicou um anúncio intitulado Teatro do Vasques oferecendo edições de dezesseis cenas cômicas de sua autoria que podiam ser adquiridas "no escritório do teatro Ginásio, ou na casa do autor, beco da Carioca, n.8" ao preço de 400 réis a unidade. 
tos da sociedade fluminense do período, poderemos ter uma noção mais aproximada das feições deste setor do mercado livreiro voltado para a dramaturgia. Afinal, a presença, nestas peças, de dispositivos que serviam para encurtar a distância entre o texto representado e o texto impresso, tais como a interpelação das audiências, o uso de grifos, itálicos, provérbios, gírias e trocadilhos são indicativos dos dois tipos de relacionamento que elas estabeleciam com seus receptores (o espectador e o ouvinte), da dupla circulação de tais textos (palco e página impressa) e de duas práticas de apropriação (a representação teatral e a leitura).

Um dos gêneros dramáticos mais bem sucedidos neste período, tanto no palco quanto na folha impressa, foi a cena cômica. Peças em ato único, que utilizavam falares e temas do cotidiano, escritas em sua maioria por indivíduos sem renome no mundo das letras, mas atuantes no mundo teatral tais como atores, pontos e cenógrafos, as cenas cômicas apresentavam um atrativo a mais que as tornavam ainda mais populares entre as mais diferentes platéias: a utilização de canções de domínio público. ${ }^{19} \mathrm{Na}$ segunda metade do século XIX, as cenas cômicas "invadiram" simultaneamente os tablados e as livrarias do Rio de Janeiro. Ao lado de títulos de autores "seletos" da literatura dramática, tanto nacionais quanto estrangeiros, as cenas cômicas podiam ser encontradas nas prateleiras dos estabelecimentos que vendiam livros na Corte. ${ }^{20}$

Algumas delas alcançaram tamanho sucesso de vendagem que permaneceram nos catálogos de algumas livrarias por mais de uma década. Encontram-se neste caso, apenas para citarmos dois exemplos, O sr. Anselmo apaixonado pelo Alcazar e Rocambole no Rio de Janeiro, ambas de autoria de Francisco Correa Vasques. O Sr. Anselmo apaixonado pelo Alcazar estreou e foi publicada pela primeira vez pela Tipografia Azeredo Leite, em 1862, e teve mais duas outras edições pela Tipografia Cruz Coutinho, a última delas no ano de 1884. Rocambole no Rio de Janeiro estreou e teve

19 Embora as cenas cômicas tenham se firmado como um gênero dramático de repercussão junto às platéias fluminenses, sua propagação não foi vista com bons olhos nos meios letrados. Os críticos teatrais e homens de letras envolvidos com as artes cênica não se furtaram a condenar seus autores acusando-os de profanar o tablado com algo que não poderia ser chamado de dramaturgia e de desvirtuarem os verdadeiros objetivos da arte, transformando o teatro em mercadoria a ser consumida por um público ávido por divertimento e lazer . Para um discussão detalhada sobre este assunto ver: MARZANO, Andrea B. Scenas comicas: Vasques e o teatro no Rio de Janeiro. Rio de Janeiro: UFF, 1999 (História, dissertação de mestrado); MENCARELLI, Fernando A. A voz e a partitura: teatro musical, indústria e diversidade cultural no Rio de Janeiro (1868-1908) e SOUZA, Silvia Cristina Martins de. As noites do Ginásio: teatro e tensões culturais na corte (1832-1868). Campinas: Ed. da Unicamp, 2002.

20 Cabe aqui lembrar que, naquele período, os livros eram vendidos em livrarias ou por vendedores ambulantes, assim como as livrarias vendiam outros artigos, além de livros. No jornal Marmota Fluminense, do dia 9 de abril de 1858, foi publicado o seguinte anúncio sobre a Livraria de Paula Brito, um dos mais importantes livreiros da cidade à época: "Loja do Bom e do Barato de Paula Brito. Praça da Constituição, n. 64. Porta larga, onde há sempre chá, letras e papel selado, charutos, objetos de escritórios, bonecas, cartas de jogar, opacas, perfumarias, romances e novelas e uma variedade infinita de coisas interessantes". Sobre as vendas realizadas por vendedores ambulantes, João do Rio deixou um testemunho bastante significativo no seu $A$ alma encantadora das ruas, ao mencionar que José de Alencar e Joaquim Manuel de Almeida utilizavam escravos de ganho para vender seus livros, que carregavam em balaios pelas ruas do Rio de Janeiro. 
sua primeira edição em 1868, uma segunda edição em 1870 e mais uma em 1884, todas elas pela Tipografia Cruz Coutinho. Publicadas in oitavo e in décimo-segundo, utilizando papel barato e forma brochada, estes textos foram editados em um momento no qual passavam a conviver diferentes sistemas editoriais no mercado livreiro do Rio de Janeiro.

Muitas destas edições foram bancadas unicamente pelos editores, que nelas percebiam um grande potencial para comercialização, ao passo que outras foram editadas por subscrição, havendo ainda aquelas que vieram à luz sob conta e risco dos próprios autores, que também se incumbiam de vender os exemplares nas ruas, nas suas residências ou nas bilheterias dos teatros. ${ }^{21}$ Por serem curtos, os textos das cenas cômicas dispensavam um tratamento editorial visando adaptá-las à prática da leitura em voz alta, pois se ajustavam como uma luva à necessidade de garantir um tempo de elocução limitado de modo a não cansar a audiência, sem contar que facilitavam a memorização da intriga pelos ouvintes.

Mas outros dispositivos formais nelas presentes emergem como elementos que servem para elaboramos algumas reflexões sobre as relações entre palco e página. Tais elementos, é preciso que desde logo seja esclarecido, serão aqui pensados não como representações de práticas orais, mas como instrumentos (implícitos ou explícitos) que destinavam tais textos não apenas aos leitores solitários, mas também aos ledores, isto é, pessoas que liam em voz alta para uma audiência que não dominava a prática da leitura extensiva e era, na maior parte das vezes, não alfabetizada. Um deles é a presença de grifos em certas palavras ou expressões, como ocorre com o texto da cena cômica intitulada O Sr. Joaquim da Costa Brasil, de autoria de Francisco Correa Vasques. ${ }^{22}$

Logo no início do texto, o personagem que dá título à peça apresentase ao público utilizando-se das seguintes palavras:

WSS têm na sua presença o Sr. Joaquim da Costa Brasil!... Sou filho de pais portugueses (...). Gozo de uma fortuna colossal; tenho muito pouca idade, mas já sou independente (...). Nas minhas algibeiras WSS encontrarão sempre - rios de dinheiro e minas de ouro. Possuo baías de brilhantes, fazendas onde há lagoas de prata, rodeadas por um mato grosso de fumo e café. Não pensem que é Maranhão; além de todas estas riquezas ainda tenho por mim São Pedro, São Paulo, Santa Catarina e Espírito Santo, santos de minha cordial devoção. ${ }^{23}$

21 Em anúncio publicado no Jornal do Comércio do dia 26 de outubro de 1866, uma tipografia localizada a rua São José, n. 14, dizia que naquela casa fazia-se "qualquer impressão com brevidade e por preço razoável", o que nos leva a sugerir que tais edições tinham como alvo autores com pouco dinheiro para editar suas obras.

22 Esta cena cômica estreou no dia 26 de junho de 1860 e foi publicada alguns dias após a estréia pela Tipografia J.J. da Rocha.

23 VASQUES, Francisco Correa. O Sr.Joaquim da Costa Brasil. Rio de Janeiro: Tipografia de J.J. da Rocha, 1866, p.1. (sublinhados no original) 
Neste caso específico, os sublinhados serviam para destacar os nomes das províncias do império, não faltando até mesmo um trocadilho que resulta da justaposição de duas palavras dando origem a uma terceira. Se no tablado estas partes deveriam ser complementadas pelas performances dos atores, no texto impresso os grifos funcionavam como sinais enviados ao ledor, indicando-Ihe que deveria reproduzi-los de modo a atrair a atenção de sua audiência para tais palavras.

Tal como os sublinhados, os grifos em itálico tinham uma função no texto impresso. É exemplar, neste sentido, o texto da cena cômica intitulada Aí! Cara Dura!, também de autoria de Francisco Correa Vasques. Publicada sob forma de folhetim, na Gazeta da Tarde do dia 24 de janeiro de 1884, esta peça já havia sido representada no teatro Santana com grande sucesso, tanto que serviu de fonte de inspiração para que o maestro Cavalier Darbilly compusesse uma polca em homenagem ao Vasques a que deu o mesmo título da peça. ${ }^{24}$

Nela o protagonista entrava em cena interpelando os espectadores com as seguintes palavras:

Não se assustem meus senhores...O cara dura sou eu! Não sei, nem mesmo precisar a razão porque assim me apelidam; porém, o que é verdade, é que não dou um passo, não vou a parte alguma, sem que não ouça a gritar: Aí! Cara dura! (...) (cantando)

Se me esqueço de pagar

Se o calote vem a lume,

Não o faço por velhaco

É por estar neste costume!

Assim vive muita gente,

Assim passa por honrado...

Cara Dura no presente,

Sem vergonha no passado. ${ }^{25}$

24 A partitura da polca foi impressa pela tipografia Buschmann e Guimarães. Vasques escreveu uma série de foIhetins para a Gazeta da Tarde de 18 de outubro de 1883 a 17 de abril de 1884. A esta série ele deu o título de Scenas Comicas. O motivo que o levou a publicar o texto da peça no jornal foi, segundo ele próprio, a falta de assunto para preencher aquele espaço o que o fazia impingir aos leitores algo que já conheciam dos tablados. Tal afirmação, todavia, pode ser também entendida como uma maneira de chamar a atenção para um leitor que poderia recordar, através da leitura do folhetim, a encenação de uma peça que fizera bastante sucesso no teatro Santana. Por outro lado, o fato de ser folhetinista da Gazeta da Tarde propiciava a Vasques a oportunidade de publicar o texto sem custos e isto numa ocasião em que as publicações de suas peças teatrais rarearam significativamente, provavelmente em função dos problemas financeiros que este ator e dramaturgo vivenciou nos últimos anos de sua vida. Para maiores informações sobre a vida de Francisco Correa Vasques ver: MARZANO, Andrea B. Respeitável público! Universo teatral, trajetória e história social do Rio de Janeiro (1839-1892). Rio de Janeiro: UFF, 2005. (História, tese de doutorado).

25 Gazeta da Tarde, 24 de janeiro de 1884. (itálicos no original). 
O itálico, tal como aqui utilizado, pode ser considerado um dispositivo que incidia sobre a construção do sentido do texto, fazendo com que certas palavras e expressões fossem imediatamente visíveis aos olhos dos ledores, sugerindo que eles as destacassem para seus ouvintes através de uma pausa, da elevação da voz, da elaboração da gestualidade ou de outro artifício. No caso específico desta cena cômica, é a gíria "cara-dura", que corresponde ao atual "cara-de-pau", o termo que o autor colocava em evidência sendo justamente a gíria, pelo que tem de insólito, que conferia certa picardia à personagem e adequava-se como uma luva para aliciar certa simpatia humorística por parte de leitores e ouvintes. Desta maneira, vê-se que ambos - grifos e itálicos - permitiam que uma parte da ação fosse restaurada no texto impresso brindando os ouvintes com a possibilidade de imaginar ou reconstruir para si próprios as performances dos atores, as quais já conheciam das encenações nos teatros.

As edições impressas podiam ainda reduzir a distância entre palco e página por meio de rubricas contendo as indicações cênicas propostas pelo autor, permitindo que parte da encenação passasse para o interior do texto impresso e fazendo com que os leitores e ouvintes imaginassem as entradas, saídas, gestos e movimentos dos atores.

A cena cômica O Sr.Manuel Vieira assistindo à representação do drama Os Milagres de Santo Antônio, de autoria do ator Dias Guimarães, é exemplar do que vimos falando. Logo no início do texto o dramaturgo apresenta as seguintes indicações:

Um gabinete sem pretensões, com pouca mobília, e essa mesma demasiadamente modesta.

O Sr.Manoel Vieira entra; tira o chapéu; limpa-o com o lenço tabaqueiro; coloca-o sobre a mesa; e reparando de repente nos espectadores diz atrapalhado consigo mesmo: $(\ldots.){ }^{26}$

No caso das indicações cênicas, um elemento deve ser ressaltado. Se elas apresentavam-se como uma vantagem adicional para o autor, permitindo que atores e ledores em lugares diversos pudessem duplicar o texto original de maneira similar, tal dispositivo não excluía a possibilidade de o texto ser apropriado de maneira diferente por alguns agentes.

No caso específico dos atores, o uso recorrente da prática de introduzirem falas inexistentes no original no momento da representação é um

26 GUIMARÃES, Dias. O Sr. Manoel Vieira assistindo à representação do drama Os milagres de Santo Antônio. Rio de Janeiro: Tipografia Popular de Azeredo Leite, 1864, p.1. De acordo com BASTOS, Antônio de Souza. Carteira do artista: apontamentos para a história do teatro português e brasileiro, Lisboa, Bertrand, 1898, p.43, o ator português Dias Guimarães partiu para o Brasil muito novo a fim de seguir a carreira comercial. Pouco depois entrou para o teatro onde trabalhou até 1881, quatro anos antes de sua morte, ocorrida no Rio de Janeiro. Foi autor de um drama em três atos - O poder do ouro - e das cenas cômicas O Sr. Manuel Vieira assistindo à representação d'Os Milagres de Santo Antônio e Cerração no mar. 
indicativo das possibilidades de apropriações que escapavam à intenção dos dramaturgos. Não foram poucas, inclusive, as reclamações emitidas por censores e críticos teatrais recriminando o fato de que certos atores de tal maneira "apepinavam" os textos que acabavam por descaracterizálos. ${ }^{27} \mathrm{~A}$ este respeito vale reproduzir o trecho de uma crítica publicada $\mathrm{n}$ ' $\mathrm{O}$ Martinho: jornal de recreio que trata dos vivos e dos mortos, do dia 29 de junho de 1851, na qual podia-se ler:

De muito tempo que reparamos na sem cerimônia da Sra. Montani sobre a cena, que se julga em sua casa para rir, folgar, dizer ditos espirituosos, e nada escrevemos (...); mas depois que vimos que este procedimento vai lavrando, $\mathrm{e}$ que já tem atacado as Sras. Orsat, Clotilde e Velutti (...) é forçoso que digamos alguma coisa (...). O ator em cena é todo o personagem que representa, e nem um gesto deve sair desse caracter. ${ }^{28}$

Não foi outro o assunto que motivou a elaboração de um ofício redigido pelo presidente do Conservatório Dramático Brasileiro endereçado ao chefe de polícia da Corte, autoridade incumbida de manter as correções feitas nos originais censurados pelo Conservatório quando as peças fossem encenadas, algo que, segundo este ofício, estava sendo recorrentemente desrespeitado pelos atores, tanto que o presidente daquela associação dizia ser seu dever

chamar a atenção de V.Exa. [o chefe de polícia].sobre a prática introduzida nos teatros desta Corte, de proferirem na cena alguns atores palavras estranhas ao original submetido ao Conservatório. ${ }^{29}$

Ou ainda, como sublinhou Arthur Azevedo no jornal A Notícia, no ano de 1895, ao comentar uma montagem de Orfeu, com tradução de Eduardo Garrido, sem esconder sua insatisfação com a sem cerimônia de certos atores:

Os nossos atores têm o mau vezo de enxertar pilhérias de um gosto equívoco no texto de seus papéis. Anteontem, um corista (nem ao menos era um ator!)

27 "Apepinar" equivale ao "colocar cacos" da gíria atual do teatro. Ver: BASTOS, Antônio de Souza. Carteira do artista: apontamentos para a história do teatro português e brasileiro. Lisboa: Bertrand, 1898.

28 O Martinho: jornal de recreio que trata dos vivos e dos mortos, 29 de junho de 1851.

29 Biblioteca Nacional, Setor de Manuscritos, Coleção Conservatório Dramático Brasileiro (CDB). Correspondência Ativa, 04,03,030, 6 de dezembro de 1858. O Conservatório Dramático Brasileiro foi uma associação criada por homens de letras, em 1843, que recebeu do governo imperial a incumbência de censurar as peças a serem encenadas em todos os teatros da capital do Império. Apenas para que se tenha noção de quem compunha o Conservatório basta citarmos os nomes, dentre outros, de Machado de Assis, José de Alencar, Quintino Bocaiúva, Gonçalves Dias, Martins Pena e Joaquim Manuel de Macedo. Á polícia cabia dar o visto sobre as peças censuradas pelo Conservatório bem manter as alterações dos textos, propostas pelos censores, quando a peça subia à cena, função esta executada pelos juizes inspetores de teatro, que assistiam a todas as encenações nos teatros da cidade. SOUZA, Silvia Cristina Martins de. As noites do ginásio: teatro e tensões culturais na Corte (1832-1868). Já no caso dos leitores e ouvintes, pode-se dizer que embora hoje se saiba com alguma precisão o que se lia no passado, as maneiras como os leitores se apropriavam destas leituras continua sendo um exercício bem mais complexo para os historiadores. 
colaborou com Hector Crémieux e Eduardo Garrido. No segundo ato do Orfeu esse indivíduo trouxe para a cena o trono de Júpiter - Donde veio isso? Perguntou-lhe [o ator] Machado - Ali da venda do Porto, respondeu ele. Pode ser que no palco Ihe achassem muita graça; na sala o efeito é detestável. ${ }^{30}$

A prática de "apepinar" foi, como se vê, bastante arraigada, a ponto de ser localizada nas décadas finais do século e de continuar provocando críticas negativas dos homens de letras que nela viam uma maneira, por assim dizer, espúria de os atores intervirem no métier dos autores.

Dois outros dispositivos ligados diretamente à oralidade, muito utilizados nestas peças, foram os provérbios e os trocadilhos. Formas cristalizadas pela comunidade e de uso corrente no cotidiano das pessoas comuns, os provérbios já passavam, naquele período, por um processo paulatino de desvalorização por parte da cultura letrada no Brasil, sobretudo nas discussões relativas às relações entre o que se imaginava ser esta cultura letrada e uma outra considerada iletrada e às fontes de legitimidade da primeira. A questão central que perpassava tais tensões dizia respeito, entretanto, menos ao conteúdo e ao uso do trocadilho nas peças e mais aos gêneros dramáticos em que eram mais utilizados e às audiências a que se direcionavam. ${ }^{31}$

Todavia, os provérbios deram origem a várias cenas cômicas que exploravam temáticas de trânsito popular, podendo ser localizados ao longo dos textos de tais peças ou nos seus próprios títulos, tornando-se responsáveis por uma produção em muitos aspectos repetitiva, até porque, de acordo com os padrões daquela época, a originalidade era menos importante do que as retomadas de temas que "relembravam" sucessos já alcançados.

A cena cômica Zé Pereira carnavalesco, de Francisco Correa Vasques, é um exemplo apropriado do uso que alguns dramaturgos fizeram dos provérbios. No seu desfecho, o personagem Chico da Venda elabora um discurso pleno de lugares comuns, arrolando uma série de provérbios populares. Como se isto não bastasse, o dramaturgo chega a lançar mão de um jogo de inversões a partir do qual alguns provérbios conhecidos aparecem revestidos de um novo sentido moral, colocando na boca deste personagem ditos populares resignificados tais como "quem me avisa meu amigo é" ou "mais vale quem Deus ajuda, do que quem muito madruga". ${ }^{32}$

30 A Notícia, 24 de janeiro de 1895.

31 Exemplar desses procedimentos a que vimos nos referindo é o caso de Machado de Assis, que se especializou no chamado teatro de provérbios ou comédias de salão, isto é, pequenas comédias de caráter literário, que tinham por assunto e por título um provérbio, evitando, porém, a comicidade farsesca, vista como recurso de uma dramaturgia "menor", e que estabeleciam com o público uma relação bastante lúdica, pois os espectadores tinham que adivinhar qual o provérbio oculto na ação desenvolvida pelo autor. Além disto, as comédias de salão eram peças escritas para serem representadas para grupos restritos de espectadores "seletos", que se reuniam em saraus literários.

32 VASQUES, Francisco Correa. Zé Pereira carnavalesco. In: FERREIRA, Procópio. O ator Vasques. Rio de Janeiro: SNT/Funarte, 1979, p.408. 
Já nas cenas cômicas Não há fumo sem fogo; Quem casa quer casa; Com vinagre não se pega moscas; Quem casa não pensa e quem pensa não casa e Mais vale quem Deus ajuda que quem cedo madruga; Quem conta um conto acrescenta um ponto; A casa de banhos ou gato escaldado tem medo de água fria; Quem o alheio veste na praça o despe; Deus os fez e o diabo os ajuntou; Quem mais faz menos merece; O hábito não faz o monge; Quem tem boca vai a Roma e O homem põe e Deus dispõe, os provérbios servem de títulos às próprias peças e mais uma vez emergem como indícios concretos do alinhamento do discurso impresso à performance da oralidade.

No caso do trocadilho, algumas observações merecem se feitas. A moda do uso do trocadilho chegou ao Brasil através da França, onde era chamado calembourg. De tal forma seu uso fincou raízes no Rio que, para as livrarias desta cidade, a França mandava livros tais como o Dicttionaire des calembourgs et de jeux de mots, coq-à-l’ane, quolibets, quiproquó, amphijouris etc., recueillis par le baron de la Pointe et le dr. Eugéne La Gai e Bibliotheque dês calembourgs suive du petit musée drolatique. ${ }^{33}$

Longe de encontrarem-se restritos ao mundo das letras, os trocadilhos espraiaram-se pelos mais variados segmentos da sociedade tornandose de domínio público e conformando-se como um recurso de oralidade bastante utilizado, que se apresentava em perfeita sintonia com o clima da época. Não surpreende, então, que eles também fossem utilizados pelos dramaturgos em seus textos, saltando dos falares das ruas para o palco e a página impressa, tal como se pode encontrar na cena cômica Um bilhete! Um bilhete! Para o benefício do Graça!, de autoria do já aqui tantas vezes citado Vasques, que foi useiro e vezeiro de trocadilhos:

Personagem único - Guarda incógnito - Cena, o pano de boca

Não se incomode, Sr. Graça, não se incomode mais....Jesus...eu sei perfeitamente que a sua graça grassa por toda a parte; mas confunde-me com tanta bondade.... fico perfeitamente.... perfeitamente estou-Ihe dizendo... Muito agradecido, Sr. Graça! ${ }^{34}$

Nesta cena cômica, dedicada a um famoso ator cômico de nome Eduardo Graça, a palavra "graça" é usada ora como substantivo, ora como verbo ou ainda como nome de batismo, assumindo diferentes significados semânti$\cos ^{35}$ Ao longo da peça, espalham-se estes trocadilhos polissêmicos, com os quais o autor joga para tornar a linguagem gaiata e brincalhona, sendo justamente os diferentes entendimentos dos seus significados que degeneram

33 Ver: BROCA, Brito. Teatro das letras, p.93-98.

34 VASQUES, Francisco Correa. Um bilhete! Um bilhete! Para o benefício do Graça!. Rio de Janeiro: Tipografia Cruz Coutinho, 1863

35 Eduardo José da Graça foi um ator português, radicado no Brasil, que se tornou bastante famoso entre os críticos teatrais, dentre eles Machado de Assis. 
em hilaridade. Uma hilaridade que, deve-se acrescentar, cabia ao ledor reproduzir para seu público ouvinte através de recursos sonoros e gestuais.

Por fim, mas não em último lugar, deve-se reservar um espaço para elaborarmos alguns comentários a respeito da função que a música exerceu nesta literatura dramática. Não são poucas as referências a músicas de domínio público nas edições destas peças, que aparecem, na maior parte dos casos, acompanhadas das indicações de como deveriam ser cantadas.

Na cena cômica Os Efeitos da Gran-Via, de Augusto Fábregas, a indicação da música aparece da seguinte maneira:

(Ao subir o pano, a orquestra preludia um motivo da Gran Via - O personagem, tipo caricato, entra colérico)

Passa fora! Isto é deveras!

Para fazer arrelia!

Não posso andar quatro passos

Sem ouvir tocar Gran Via

De tanto cair em graça

Chega mesmo a ser mania

No gênero "cacetada"

'sta na porta a tal Gran Via

Gran Duquesa, Orfeu, Mascote

Já lá tiveram seu dia...

Passou-lhes a perna a todas

A tal Sra. Gran Via

Na cidade e nos subúrbios

Lavra a mesma epidemia

Rabecas, pianos, gaitas

Só tocam isto - Gran Via. ${ }^{36}$

Fábregas remete-se, aqui, ao frisson provocado no Rio de Janeiro desde que a revista A Gran Via foi encenada por uma companhia italiana de revistas e zarzuelas que esteve em temporada artística na cidade no ano de $1888,{ }^{37}$ comparando o sucesso que a música desta opereta alcançou com o de outras revistas e operetas - Gran Duquesa de Gerolstein, Orfeu nos Infernos e A Mascote - atingindo um público, ao que parece, bastante

36 FABREGAS, Augusto. Cenas cômicas, monólogos e cançonetas exibidos nos teatros do Rio de Janeiro. Rio de Janeiro: Imprensa Mont Alverne, 1893. Conseqüências da Gran-via foi recitada pela primeira vez em agosto de 1889 pelo jovem ator Romeu Bastos, a quem o autor dedicou a peça. Augusto Fabregas foi também jornalista. Do romance $O$ primo do padre Amaro, Fábregas extraiu um drama que fez grande sucesso. Além de As conseqüências da Gran Via escreveu a canção Fandanguassú (grande êxito do ator Leonardo) e os monólogos Festa no céu, Jogo dos bichos, Mãe Joana e Quando a desgraça penetra. Ver: BASTOS, Antônio de Souza. Carteira do artista: apontamentos para a história do teatro português e brasileiro. Lisboa: Bertrand, 1898, p.614.

37 A Gran Via, conforme anúncio publicado em maio de 1888 no Jornal do Comércio e na Gazeta de Notícias, era uma revista em um ato e quatro quadros musicada pelos maestros Chueca e Valverde, que faziam parte da Companhia Espanhola de Zarzuelas e Bailados, que esteve em turnê no Rio naquele ano, no teatro Lucinda. Os efeitos da Gran Via era uma "revista cômica, lírica, política e internacional" em um ato, dez quadros e uma apoteose, musicada pelos mesmos Chueca e Valverde, e posta em cena por esta mesma companhia de zarzuelas. No dia 26 de maio de 1888, a Gazeta de Notícias publicou o anúncio da récita conjunta destas duas revistas noticiando estar a Grã-Via na trigésima sexta representação e Os efeitos da grã-via na décima primeira. 
diversificado, já que este ouvia e tocava de rabecas e gaitas, instrumentos de caráter mais "popular", ao piano, instrumento tido como mais "nobre". Desta maneira, o autor estabelecia com o leitor de sua peça uma relação estreita motivando-o a acionar um determinado arsenal cultural para decifrar o texto paródico de sua cena cômica. Ou, ainda, como fez Vasques em $O$ Ginásio de roupa nova, cena cômica escrita especialmente para a récita do dia 2 de setembro de 1864, quando o teatro Ginásio Dramático reabriu após haver passado por uma reforma que durou dois meses.

O teatro Ginásio, protagonista da peça, animado com as mudanças pelas quais passara, diria:

Com este melhoramentos pois quem poderá competir comigo? Ninguém! (...) Nada me abala! Receio unicamente das companhias que cantam (...). Contudo - Vasques disse-me que eu podia estar descansado porque enquanto eles cantassem Rossini e Bellini ele iria cantando quantas modinhas aprendesse dos maestros capadocinis; e para prova fez-me decorar a que será apresentada ao público na primeira cena cômica que ele escrever; querem ouvi-la? lá vai:

Eu gosto da cor morena

Sempre amena

Que mimosa me arrebata,

Essa cor é faceira

Feiticeira

Moreninha que me mata.

Eu gosto dos olhos dela

Quando ela

Para mim os quer volver;

Esses olhos são tão formosos,

Melindrosos

Dizem sim, até morrer

Não gosto da cor do lírio

Que delírio

Vê causar já de repente,

Nem também da cor noturna

Que da furna

O sepulcro faz patente.

Oh! Que sim, por essa cor

Do meu amor,

Me derreto, me espatifo,

Tenho febre, tenho frios,

Calafrios,

Tenho gosma, tenho tifo. ${ }^{38}$

38 VASQUES, Francisco Correa. O ginásio de roupa nova. Rio de Janeiro: Tipografia Azeredo Leite, 1864. (sublinhados no original). 
Diferentemente da peça de Fábregas, cuja canção evocada é parte de uma revista de autoria conhecida, O Ginásio de roupa nova evoca uma canção de autoria desconhecida, mas de bastante sucesso. Tal fato, além de ser um indício da presença da oralidade neste texto, é também indicativo da força de uma herança da tradição musical de feitura coletiva e anônima, que fazia com que várias canções circulassem livremente na boca de compositores e autores desconhecidos - os trovadores, capadócios ou cantadores de rua -, prática muito corrente no período que vimos trabalhando.

Vale lembrar, ainda, que a expressão capadócio era uma gíria brasileira daquele século que significava o indivíduo matreiro e maneiroso e ao dela utilizar-se em sua peça, Vasques guindava ao palco e à página impressa usos lingüísticos do dia-a-dia, provocando reações cômicas. Para além deste fato, ao utilizar a expressão capadócio na sua "versão" em italiano, língua por excelência das óperas mais popularizadas na Europa e no Brasil, Vasques atribuía aos trovadores e cantadores de rua o status de "maestros" apontando, ainda que implicitamente, para a importância que, na sua visão, aqueles indivíduos assumiam como divulgadores culturais, caminhando na contramão de uma certa crítica que utilizava o termo de maneira desairosa para desqualificar indivíduos sem formação musical, que se dedicavam a gêneros musicais considerados "menores".

Mas isto ainda não é tudo. O fato de fazer com que o protagonista da sua cena cômica tivesse que "decorar" os versos de uma canção da qual Vasques não citava o título, mas os habitantes do Rio sabiam muito bem tratar-se de Mulatinha do Caroço, já à época imortalizada em várias coleções de liras ${ }^{39}$ deveria soar hilariante aos leitores da peça ou aos ouvintes e espectadores dos teatros, o que mais uma vez reforça a noção de que as ligações de troca e cumplicidade entre rua e tablado eram intensas e foram bastante exploradas por vários dramaturgos.

Mas, o mais importante, aqui, é ressaltar o papel que a música assumiu para esta produção dramática que passava a ser impressa, a ponto

39 De tanto sucesso que fez, Mulatinha do caroço foi publicada em três cancioneiros. Em 1881, no cancioneiro Serões Baianos, coleção de recitativos, modinhas e canções. Bahia: Livraria Econômica de Tolentino Álvares e Irmão; em 1890, no cancioneiro MORAIS FILHO, Melo. (org.) Cantares Brasileiros - cancioneiro fluminense. Rio de Janeiro: Jacinto dos Santos/Cruz Coutinho, 1890 e, em 1895, no Cantor das modinhas brasileiras: coleção completa de lindas modinhas, lundus e recitativos. Rio de Janeiro: Laemmert, 1895. Nas três edições, ela aparece como lundú, e não como modinha, tal como na peça de Vasques. Na segunda metade do século XIX, modinhas e lundús eram classificações que tinham caráter aleatório e confuso e se confundiam constantemente. Data deste período, todavia, a construção de uma imagem, que ainda perdura entre os estudos sobre a música brasileira, a saber, a de que a modinha teria uma origem erudita européia sendo, portanto, mais própria aos salões, ao passo que o lundu seria uma manifestação de negros, originada da dança e dos batuques sendo, como decorrência, impróprio para os ambientes "seletos" dos salões. O fato de Vasques ter mencionado a canção como modinha nos leva a sugerir que tal menção, vinda de um autor condenado por fazer uma dramaturgia demasiadamente popular e supostamente sem qualidade, talvez fosse uma maneira de ele elevar a canção a um patamar mais aceitável, bem como sua cena cômica, por serem ambos considerados gêneros "menores". Sobre modinhas e lundús ver para este assunto: FERLIN, Uliana D.C. A polifonia das modinhas: diversidade e tensões musicais no Rio de Janeiro na passagem do século XIX ao XX. São Paulo: Unicamp, 2006 (História, dissertação de mestrado). Sobre gêneros literários "altos" e "baixos" ver: SOUZA, Sílvia Cristina Martins de. As noites do ginásio: teatro e tensões culturais na Corte (1832-1862). 
de dispensar maiores referências a certas melodias bastando, para que fossem identificadas, a alusão aos primeiros acordes de algumas canções ou simplesmente a reprodução de seus versos, sem menção à melodia ou sequer ao título, como fizeram Fábregas e Vasques.

Diante do sucesso que tais textos teatrais desfrutaram no Rio de Janeiro na segunda metade do século XIX, a ponto de contribuírem de forma decisiva para o enraizamento do teatro musicado e do desenvolvimento do mercado livreiro na cidade, não surpreende que eles tenham motivado incidentes envolvendo furto literário ou plágio. Um deles teve como protagonistas os atores e dramaturgos Francisco Correa Vasques e Antônio de Souza Martins em torno da autoria da cena cômica Por causa da Emília das Neves. ${ }^{40}$

Emília das Neves foi uma célebre atriz trágica portuguesa, que se apresentou no Rio entre junho e setembro de 1864 no teatro Lírico Fluminense. Sua temporada nesta cidade foi marcada pela procura desenfreada por bilhetes para suas récitas a ponto de o empresário daquele teatro organizar um sistema de venda de assinaturas de camarotes para seus espetáculos e de publicar, no Jornal do Comércio, um aviso no qual rogava aos assinantes do teatro, que desejassem ficar com seus camarotes, e por ser de praxe que os assinantes tivessem preferência, "o obséquio de mandarem assinar até (...) ao meio dia, pois que dessa hora em diante não se atenderá a reclamação alguma, e serão entregues [os camarotes] a quem os desejar". ${ }^{41}$

Foi neste clima que, no dia 21 de junho, o teatro de São Januário anunciou, como parte do seu espetáculo, a cena cômica Por causa da Emília das Neves, cuja autoria foi atribuída ao ator Martins. ${ }^{42}$ Três dias depois, o teatro Ginásio anunciaria a representação desta mesma cena cômica, só que ressaltando ser ela de autoria do ator Vasques. No dia 26 de junho, o Ginásio e o São Januário anunciaram a representação de Por causa da Emília das Neves como parte de suas respectivas récitas, e o anúncio do São Januário veio acrescido da informação de que a referida cena cômica fora escrita e desempenhada "pelo ator Martins, dedicada e aceita pela exímia artista portuguesa e representada pela primeira vez em sua presença". No dia 10 de julho, este episódio acabou tendo um desfecho. Em nota publicada na seção anúncios de teatros do Jornal do Comércio podia-se ler que

o ator Francisco Correa Vasques acaba de imprimir o despropósito cômico intitulado Por causa da Emília das Neves, dedicado à mesma senhora. A edição

40 Antônio de Souza Martins nasceu em Itaguaí (RJ) e foi para a cidade do Rio de Janeiro estudar no Colégio Vitório com a intenção de posteriormente cursar medicina. Todavia, abandonou os estudos para ingressar no mundo teatral. Como ator, Martins notabilizou-se no desempenho do papel do moleque da comédia O Demônio Familiar, de José de Alencar. Além de ator, Antônio de Souza Martins foi empresário e dramaturgo, tendo publicado e encenado nove cenas cômicas de sua autoria. Ver: BASTOS, Antônio de Souza. Carteira do artista: apontamentos para a história do teatro português e brasileiro, p.47.

41 Jornal do Comércio, 27 de agosto de 1864.

42 Ver para este incidente o Jornal do Comércio, 27 de agosto de 1864, 31 de dezembro de 1864, 26 de outubro de 1866. 
deste trabalho acha-se desde já à venda no escritório do teatro do Ginásio, cujo produto será depositado em mão da Exma. Da. Emília das Neves (que aceitou de bom grado este depósito) para ser aplicado em favor do Asilo da Criança Desvalida em Portugal. ${ }^{43}$

Impossível saber quem, na verdade, era o autor da peça. De concreto é possível afirmar que, depois de ter sido publicada por Vasques, ele passou a usufruir do estatuto autoral sobre a obra. Porém, são outros os pontos que interessam aqui destacar. Em primeiro lugar, que de tal forma estes textos alcançavam notabilidade e prometiam retornos financeiros, que muitos indivíduos se animaram a relacioná-los a seus nomes utilizando-se, para tanto, de estratégias muitas vezes duvidosas, gerando disputas e tensões em torno da publicação dos mesmos. E, em segundo lugar, que a publicação de textos teatrais da forma como passou a ser feita a partir daquele período, marcava um cenário de disputa e consolidação de um direito igualmente novo: o do autor sobre sua criação, nos planos financeiro e artístico, e não surpreende que, nas décadas seguintes, as querelas (judiciais ou não) em torno da questão da propriedade literária tivessem aumentado apontando para as sutilezas envolvidas nos circuitos de produção cultural naquele contexto.

\section{Considerações finais}

Em carta enviada no dia 8 de setembro de 1902 ao Mr. Lansac, Machado de Assis manifestou preocupação com a difusão de seus escritos ao tratar das provas da segunda edição do seu volume de contos Várias Histórias, que se encontrava em fase de preparação na França pela editora Garnier, da qual Lansac era procurador. ${ }^{44} \mathrm{O}$ aspecto da composição tipográfica, de acordo com os termos da referida carta, não causou boa impressão ao escritor e lhe pareceu inconveniente para sua obra, por ter o aspecto e o valor de um "livrinho", de uma daquelas edições baratas tão comuns nas livrarias fluminenses, o que levou Machado a concluir a carta com as seguintes palavras:

Je vous prie, Monsieur Lansac, de transmettre ces considérations à Monsieur Garnier, qui reconnêtra la justesse, et compreendra la convenance d’ordonner quelque chose pour éviter à temps ce eu je crois préjudicable à notre affaire. ${ }^{45}$

As preocupações de Machado não estavam desprovidas de justificativa. De acordo com as regras do sistema editorial vigentes no início do século

43 Jornal do Comércio, 10 de julho de 1864. Esta cena cômica foi publicada pela Tipografia Azeredo Leite.

44 A partir da morte de Baptiste Louis Garnier, ocorrida em 1893, seu negócio passou para seu irmão Hipolite e a livraria ficou sob a direção de Julien Lansac que, na verdade, já a gerenciava desde 1889.

45 Exposição comemorativa do sexagésimo aniversário de falecimento de Joaquim Maria Machado de Assis, 20/IX/190820/IX/1968. Rio de Janeiro: Biblioteca Nacional, 1968. 
XX, a notoriedade do autor era importante para a publicação e difusão de uma obra, do que decorria uma preocupação adicional com o aspecto final da edição, sobretudo quando se tratava de um homem de letras de nomeada. Ou, dito de outra forma, o valor da obra poderia ser medido pela "má" apresentação do volume ou por uma apresentação que o aproximava dos livros baratos e populares.

Mas um outro aspecto emerge desta carta, através da maneira como Machado recorreu a Lansac para que este intercedesse junto a Garnier, antes que sua obra viesse a público com o aspecto semelhante ao das edições baratas evitando "à temps ce que je crois préjudicable à notre affaire". Se esta apreensão manifesta, por um lado, a preocupação justificável deste autor sobre sua criação e a difusão de suas obras ela explicita, por outro lado, um preconceito de sua parte. Nunca é demais lembrar, todavia, que este preconceito em relação aos tais "livrinhos", editados às pressas, ao sabor do grande público e ao alcance dos mais variados bolsos, não esteve restrito a Machado de Assis.

Se naqueles tempos estas publicações não foram consideradas literatura de boa qualidade, nas décadas seguintes tal situação não sofreu mudanças, o que fez com que elas paulatinamente perdessem seu prestígio e seu "valor de mercado", embora tenham contribuído de maneira efetiva para dar vida e dinamizar toda uma produção editorial desde fins dos anos 1850, no Rio de Janeiro.

A história e a literatura, por sua vez, descartaram tais "livrinhos" e elegeram para seu campo de estudo um conjunto de obras e autores que, nos dias de hoje, passam a impressão de terem atuado de maneira isolada e triunfante naquele contexto. Porém, o que a documentação aqui trabalhada nos permite perceber, é que além dos escritores celebrados pela memória do teatro brasileiro, inúmeros outros hoje totalmente desconhecidos, tais como Francisco Correa Vasques, Dias Guimarães, Augusto Fábregas, Antônio de Souza Martins e Thomaz Aquino Borges, atuaram a seu lado e conseguiram, em muitos casos, difundir seus textos com bastante sucesso.

À parte disto, acreditamos que as palavras de Machado são sugestivas e se adequam aos nossos objetivos por denotarem que os escritores do século XIX (fossem eles de renome ou não) tinham consciência da importância da composição tipográfica para um livro e de como o aspecto material de um texto impresso carregava marcas das realidades sociais às quais uma determinada impressão tipográfica era destinada. É exemplar, neste sentido, o caso de Joaquim Norberto de Souza e Silva. Homem de letras atuante no Instituto Histórico e Geográfico Brasileiro, Joaquim Norberto acertou com Garnier a encomenda e publicação de um conjunto de obras de sua autoria em 20 de agosto de 1862. Dentre elas, chamam atenção quatro obras, cujos títulos indicam serem livros de culinária e lazer, a saber, O novo cozinheiro do Brasil, A nova doceira brasileira, Livro de sortes para 
as noites de S. Antônio, S. João, S. Pedro e S. Ana e Livro das famílias brasileiras para entretenimento nas noites de reuniões. No contrato firmado com Garnier, Joaquim Norberto fez questão de que estas quatro obras fossem publicadas sem indicação de autoria, provavelmente por considerá-las comprometedoras para alguém com prestígio intelectual como ele. Trata-se, sem dúvida, de livros escritos em gêneros populares e que, a julgar pela tiragem maior em relação às demais obras listadas neste contrato, pareciam prometer retorno econômico mais seguro o que, todavia, não animou seu autor a querer relacioná-los a seu nome. O fato de Garnier aceitar publicálos sem autoria garantia-lhe, por sua vez, que mantivesse um padrão para suas edições não sendo confundido com os editores de brochuras baratas e de autores de pouco ou nenhum renome. ${ }^{46}$

De tudo o que aqui foi dito, enfim, acreditamos ser possível afirmar, com Chatier, que os efeitos estéticos e intelectuais dos significados produzidos pelos textos impressos são essenciais para a compreensão, "em toda sua historicidade, das múltiplas formas de recepção e de apropriação dos textos, sejam eles literários ou não" e que devemos estar sempre atentos para o fato de que as estratégias de publicação sempre moldaram as práticas de leitura criando novos gêneros de textos e novas fórmulas de publicação, para não incorrermos em uma leitura etnocêntrica, que parte do pressuposto de que as obras e gêneros literários são invariáveis e universais. ${ }^{47}$

46 Ver para maiores detalhes sobre este contrato entre Joaquim Norberto e Garnier: LAJOLO, Marisa e ZILBERMAN, Regina. O preço da leitura: leis e números por detrás das letras. São Paulo: Ática, 2001, p.103-105.

47 CHARTIER, Roger. Formas de oralidade e publicação impressa. In: Do palco à página: publicar teatro e ler romances na Idade Moderna (séculos XVI-XVIII). Rio de Janeiro: Casa da Palavra, 2002, p.37. 